\title{
Direct radiative effect of aerosols emitted by transport: from road, shipping and aviation
}

\author{
Y. Balkanski ${ }^{1}$, G. Myhre ${ }^{2,3}$, M. Gauss ${ }^{2,}{ }^{*}$, G. Rädel ${ }^{4}$, E. J. Highwood ${ }^{4}$, and K. P. Shine ${ }^{4}$ \\ ${ }^{1}$ Laboratoire des Sciences du Climat et de l'Environnement, UMR 8212, IPSL, CEA-CNRS-UVSQ, Cedex, France \\ ${ }^{2}$ Department of Geosciences, University of Oslo, Oslo, Norway \\ ${ }^{3}$ Center for International Climate and Environmental Research-Oslo (CICERO), Oslo, Norway \\ ${ }^{4}$ Department of Meteorology, University of Reading, Reading, UK \\ *now at: Norwegian Meteorological Institute, Oslo, Norway
}

Received: 2 November 2009 - Published in Atmos. Chem. Phys. Discuss.: 21 January 2010

Revised: 6 May 2010 - Accepted: 6 May 2010 - Published: 17 May 2010

\begin{abstract}
Aerosols and their precursors are emitted abundantly by transport activities. Transportation constitutes one of the fastest growing activities and its growth is predicted to increase significantly in the future. Previous studies have estimated the aerosol direct radiative forcing from one transport sub-sector, but only one study to our knowledge estimated the range of radiative forcing from the main aerosol components (sulphate, black carbon (BC) and organic carbon) for the whole transportation sector. In this study, we compare results from two different chemical transport models and three radiation codes under different hypothesis of mixing: internal and external mixing using emission inventories for the year 2000. The main results from this study consist of a positive direct radiative forcing for aerosols emitted by road traffic of $+20 \pm 11 \mathrm{~mW} \mathrm{~m}^{-2}$ for an externally mixed aerosol, and of $+32 \pm 13 \mathrm{~mW} \mathrm{~m}^{-2}$ when $\mathrm{BC}$ is internally mixed. These direct radiative forcings are much higher than the previously published estimate of $+3 \pm 11 \mathrm{~mW} \mathrm{~m}^{-2}$. For transport activities from shipping, the net direct aerosol radiative forcing is negative. This forcing is dominated by the contribution of the sulphate. For both an external and an internal mixture, the radiative forcing from shipping is estimated at $-26 \pm 4 \mathrm{~mW} \mathrm{~m}^{-2}$. These estimates are in very good agreement with the range of a previously published one (from -46 to $-13 \mathrm{~mW} \mathrm{~m}^{-2}$ ) but with a much narrower range. By contrast, the direct aerosol forcing from aviation is estimated to be small, and in the range -0.9 to $+0.3 \mathrm{~mW} \mathrm{~m}^{-2}$.
\end{abstract}

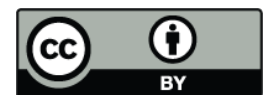

Correspondence to: Y. Balkanski (yves.balkanski@lsce.ipsl.fr)

\section{Introduction}

Although the direct radiative forcing of aerosols has been the focus of numerous studies, few have tried to evaluate the contribution of the transportation sector to this forcing. Transportation by road traffic, shipping or aviation is projected to grow significantly in the next decades. Hence, it is important to determine its contribution to the overall atmospheric burden of black carbon, organic carbon and sulphate aerosols. Here, we present estimates of the direct radiative forcing of the three main aerosol components emitted by transportation.

The main aerosol components produced from road, shipping and aircraft transport are: black carbon (or soot) which we will refer as BC, organic carbon (OC) and sulphate. Previous studies concentrated either on one component of the aerosol (Capaldo et al., 1999; Petzold et al., 1999; Köhler et al., 2001; Hendricks et al., 2004; Kjellström et al., 1999) or on the contribution of a given transportation subsector to the aerosol radiative effects (Schultz et al., 2004; Lee, 2004; Sausen et al., 2005; Lauer et al., 1997; Lee et al., 2009a). A recent study from Fuglestvedt et al. (2008) gives a comprehensive view of the climate forcing from transport sectors. They contrasted the contribution of gases and of aerosols to the radiative forcing (RF) and calculate the integrated $\mathrm{RF}$ from these year 2000 emissions over time horizons of 20 , 100 and 500 years. This approach is similar to the global warming potential approach adopted by the Kyoto Protocol, except that the integrated RF was not normalized to the effect of $\mathrm{CO}_{2}$. It appears from Schultz et al. (2004), from Fuglestvedt et al. (2008), and from the studies mentioned above, that radiative forcing of $\mathrm{BC}$ from road transport dominates the forcing from the two other contributions of $\mathrm{OC}$ and sulphate. Hence, the road sector as a whole exerts a positive

Published by Copernicus Publications on behalf of the European Geosciences Union. 
aerosol forcing on climate. In contrast, the radiative forcing from particles or sulphur species emitted by shipping is dominated by sulphate and hence exerts a negative aerosol forcing on climate.

Lauer et al. (2007) assessed the effect of international shipping on aerosols and clouds. Their simulations used three different ship emission inventories and calculated the resulting aerosol loads and direct and indirect forcings. The direct aerosol radiative forcing was estimated to be between -13 and $-11 \mathrm{~mW} \mathrm{~m}^{-2}$ in all-sky conditions, more than an order of magnitude less than their estimates of the indirect forcing, which ranged from -600 to $-190 \mathrm{~mW} \mathrm{~m}^{-2}$ depending on the inventory used and are much more negative than the direct forcing estimated by Fuglestvedt et al. (2008).

We want here to establish the direct radiative forcing from aerosols produced by the transport sector: road, shipping and aviation. The inventories that are used for these three subsectors represent transport volumes for the year 2000. The use of different assumptions for aerosol mixing allows the quantification of the effect of enhanced absorption from $\mathrm{BC}$ when $\mathrm{BC}$ is internally mixed with other particles, such as OC and sulphate. These simulations allow us to estimate the part of the overall climate impact of human activities for which the transport sector is responsible.

Several studies have shown that the absorption of BC is enhanced if it is mixed with other particles (internal mixture) rather than separated from other particles (external mixture) (Bond et al., 2006; Fuller et al., 1999; Haywood and Shine, 1995). In the atmosphere BC is observed to be in a combination of internal and external mixture (Cheng et al., 2006; Hara et al., 2003; Mallet et al., 2004; Wentzel et al., 2003). Increasing the absorption for hydrophilic BC particles by $50 \%$ (but with no change for the hydrophobic BC particles) has been suggested as a simple method to account for the internal mixture (Bond et al., 2006). This is discussed in more detail in Sect. 3.1. Using this approach the radiative forcing due to $\mathrm{BC}$ increases from $0.26 \mathrm{~W} \mathrm{~m}^{-2}$ to $0.33 \mathrm{~W} \mathrm{~m}^{-2}$ when simulating its change over the industrial era (a $28 \%$ increase) (Myhre et al., 2009). This hypothesis of internal mixing represents a coating on the BC particles and increases the RF less than a homogeneous internal mixture as assumed in previous radiative forcing calculations (Bond et al., 2006).

We compare the forcings calculated by two different Chemical Models (CTMs) with two different assumptions for aerosol mixtures: externally mixed and internally mixed aerosols. The two models have their own description of hygroscopic growth and their own cloud scheme. To our knowledge, no study has compared the direct radiative forcings of transport-produced aerosols using different radiation codes. We use three radiation codes to evaluate how different assumptions related to aerosol properties influence the radiative forcing when using the same emission inventories. The estimates of the direct radiative forcing using these two assumptions for aerosol mixtures are compared to the sparse previously published estimates.
This paper is organized as follows: Sect. 2 gives a description of the emission inventories, the aerosol parameterisations and of the radiation codes used by each of the three models respectively developed at LSCE near Paris, at University of Reading and at University of Oslo. Section 3 presents the radiative forcings and contrasts them with previous estimates. Conclusions from this study are contained in Sect. 4.

\section{Description of the emission inventories, aerosol models and radiation codes}

\subsection{Aerosols and $\mathrm{SO}_{2}$ emitted from the road-transport sector}

The present work uses an emission inventory for $\mathrm{BC}, \mathrm{OC}$ and $\mathrm{SO}_{2}$ specific for road transport for the year 2000. The emissions from road transports are prescribed annually. Table 1 shows the global-mean emissions. This inventory was assembled within the QUANTIFY project (Borken et al., 2007). It distinguishes between 5 categories of vehicles that are two-wheelers, passenger cars, buses, light and heavy duty trucks. The following types of fuels are treated separately within this inventory: diesel, ethanol, biodiesel and gasoline. Evaporative losses are not accounted for in this approach. Fuel consumption was computed for 216 countries and for 12 differentiated world regions. Consumption was estimated as the product of specific fuel consumption by the transport volumes (vehicle-kilometres). As a check of this bottom-up approach the numbers obtained for fuel consumption were then compared with data for fuel sales by country as described in Borken et al. (2007). The data were averaged spatially on a $1^{\circ} \times 1^{\circ}$ grid based upon population densities for both rural and urban areas provided by the Emission Database for Global Atmospheric Research (EDGAR) (Olivier et al., 2002).

Figure 1 presents BC emissions from road transport. Emissions of BC from road transport are concentrated in a few regions that account for more than two thirds of the total emissions. Borken et al. (2007) pointed out two types of high emitters: countries where transport volumes are important such as: the United States, Japan, Germany, France, United Kingdom, Canada and Italy and countries where emission controls are lower than in the G7 group: the five biggest being China, Brazil, Russia, Mexico and India. For $\mathrm{SO}_{2}, \mathrm{BC}$ and particulate organic carbon (POC), these five countries dominate the emissions in their respective regions.

Köhler et al. (2001) estimated the contribution of road traffic to the total atmospheric black carbon for an emission inventory based on fuel consumption in 1993. This estimation of the mass of black carbon per mass of fossil fuel burnt distinguished between Organisation for Economic Co-operation and Development (OECD) countries in Europe, North America and the Pacific rim and the rest of the world. An emission factor of $2 \mathrm{gC}(\mathrm{kg} \text { fuel })^{-1}$ was applied to OECD countries 
Table 1. Mass emitted, loads and aerosol optical depth (AOD) as computed in the LSCE model for BC, OC and $\mathrm{SO}_{4}$ emitted by the three sub-sectors.

\begin{tabular}{|c|c|c|c|c|c|c|}
\hline & $\begin{array}{l}\text { Emissions } \\
\text { (Ktons yr-1) }\end{array}$ & $\begin{array}{l}\text { Load } \\
\left(\mu \mathrm{g} \mathrm{m}^{-2}\right)\end{array}$ & $\begin{array}{l}\text { AOD } \\
\times 1000\end{array}$ & $\begin{array}{l}\text { AOD } \\
\times 1000\end{array}$ & $\begin{array}{l}\text { Fraction of } \\
\text { antrophogenic AOD } \\
(\%)\end{array}$ & $\begin{array}{l}\text { Residence } \\
\text { Time } \\
\text { (days) }\end{array}$ \\
\hline ROAD subsector & & \multicolumn{5}{|c|}{ TOTAL anthropogenic } \\
\hline $\mathrm{BC}$ & 721.6 & 18.9 & 0.184 & 2.1 & 8.8 & 7.3 \\
\hline $\mathrm{OC}$ & 326.7 & $6.9^{* *}$ & 0.077 & 3.6 & 2.1 & 7.6 \\
\hline $\mathrm{SO}_{4}$ & $1894.6^{*}$ & 39.8 & 0.530 & 13.6 & 3.9 & 4.9 \\
\hline SHIPS subsector & & & & & & \\
\hline $\mathrm{BC}$ & 31.0 & 0.79 & 0.0080 & 2.1 & 0.4 & 7.3 \\
\hline $\mathrm{OC}$ & 105.0 & 2.56 & 0.031 & 3.6 & 0.7 & 7.6 \\
\hline SO4 & $7975.0^{*}$ & 113.4 & 1.660 & 13.6 & 12.2 & 4.9 \\
\hline AVIATION subsector & & & & & & \\
\hline $\mathrm{BC}$ & 5.03 & 0.03 & 0.00027 & 2.1 & 0.01 & 7.3 \\
\hline $\mathrm{OC}$ & ¡10.7 & $<0.1$ & $<0.0005$ & 3.6 & $<0.01$ & 7.6 \\
\hline $\mathrm{SO}_{4}$ & $116.4^{*}$ & 7.69 & 0.09 & 13.6 & 0.5 & 4.9 \\
\hline
\end{tabular}

* Emissions are calculated for $\mathrm{SO}_{2}$; load, optical depth, radiative forcing and load are calculated for sulphate.

** A ratio POM:OC=1.4:1 was used, where POM indicates particulate organic matter, and OC, organic carbon.
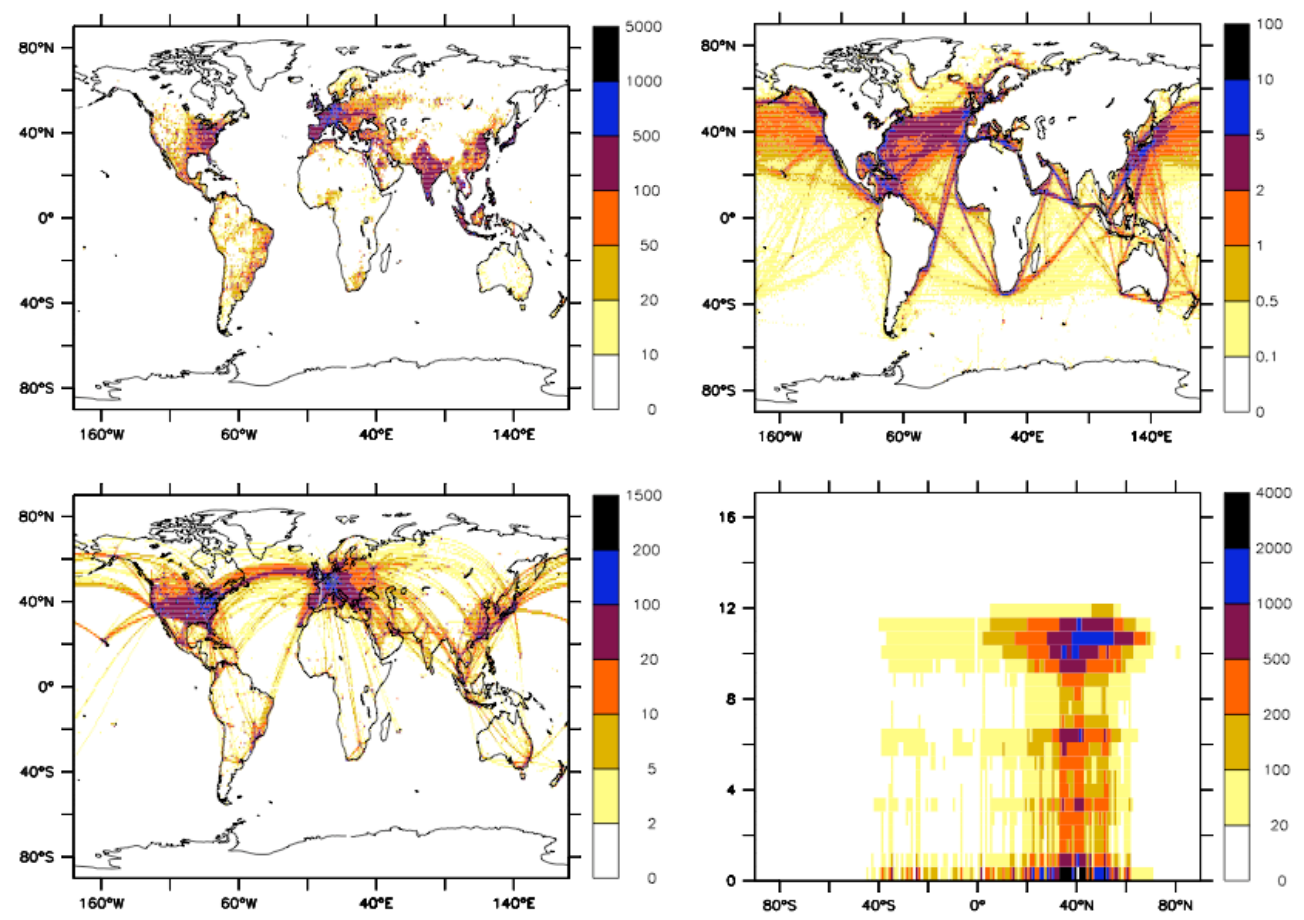

Fig. 1. Distribution of the emissions from black carbon (Tons). The upper left panel represents the emissions from road transport, and the upper right panel from shipping, the lower left panel is the column integrated emission from aircraft. The lower right panel is the vertical distribution of the $\mathrm{BC}$ emissions from aviation.

compared to $10 \mathrm{gC}(\mathrm{kg} \text { fuel })^{-1}$ for non-OECD countries. The overall amount of $\mathrm{BC}$ produced from fossil fuel and emitted by road transport was estimated to be $2.4 \mathrm{~K}_{\text {tons }} \mathrm{C} \mathrm{yr}^{-1}$. The black carbon produced by emissions from fossil fuels, biomass burning and air traffic were also included in the si- mulation. The total emissions from all these different sources

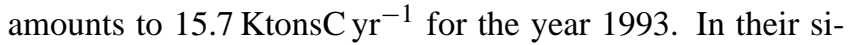
mulation, the sinks for $\mathrm{BC}$ were treated simply with a halflife of 8 days in the free troposphere (from $850 \mathrm{hPa}$ to the tropopause) decreasing to $9 \mathrm{~h}$ from the top of the boundary 
layer to the surface. Bond et al. (2004) updated the estimate of BC emitted from fossil fuels based upon data published by Yanowitz et al. (2000) that take into account the age of the car fleet that is diesel-powered. Globally these authors computed

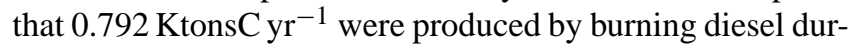

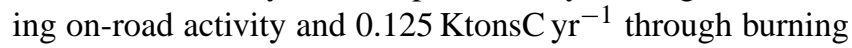
of gasoline based upon fuel-use data for 1996.

In the present work the load of black carbon emitted from

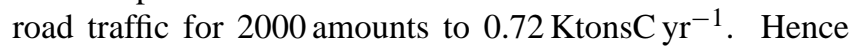
the black carbon source from roads is about one-third the estimation of Köhler et al. (2001), more similar, though still $20 \%$ smaller, than Bond et al. (2004). Aerosol loads over the regions that include G7 and emerging countries (China, Brazil, Russia, Mexico and India) are one order of magnitude greater than from other source regions.

\subsection{Aerosols and $\mathrm{SO}_{2}$ emitted from ships activity}

The inventories for $\mathrm{SO}_{2}, \mathrm{BC}$ and $\mathrm{OC}$ emitted from shipping used for this study are based upon the work of Endresen et al. (2007, 2005). Emissions from shipping are prescribed annually. Global-mean values are shown in Table 1. The fuel-based emission inventory of Endresen et al. (2007) covers the period 1925 to 2002 and considers an average ship size for civil ships with tonnage greater than 100 Gtons. The fuel consumption is then calculated as a function of the average main engine power, average main engine load, bunker fuel consumed per power unit which depends on fuel type and days at sea (see Eq. 3 in Endresen et al., 2007). Compared to the estimates of Corbet and Kohler (2003) and of Eyring et al. (2005) the estimate of fuel consumption for the year 2000 from Endresen et al. (2007) is 25\% higher. The authors attribute a large part of this difference to different assumptions concerning the numbers of days at sea. The pattern of shipping emissions follows the main routes in the Northern Hemisphere (see Fig. 1 which shows BC as a proxy for all emissions). Traffic is very dense in the proximity of the North Sea region and the main transport pathways include the coastal waters of Western Europe, Eastern North America, Eastern Asia, and the main routes used to ship oil from the Middle East.

\subsection{Aerosols and $\mathrm{SO}_{2}$ emitted from aviation}

Emissions from BC, particulate organic matter (POM) and $\mathrm{SO}_{2}$ are scaled to International Energy Agency fuel data (IEA, 2007). Aircrafts emissions are 3-D fields that are prescribed monthly to account for changes in aircraft traffic that occurs throughout the year. The magnitude of the total emissions of aerosols and precursors from aviation in terms of mass are one to two orders of magnitude smaller than from road transport or shipping.

Hendricks et al. (2004) estimated the contribution of BC emitted from aircraft to be at most a few percent of the overall atmospheric BC produced. Here, we estimate this source to represent $0.01 \%$ of the total emissions from fossil fuel sources. The size of the BC particles produced from aircraft is much smaller than that from other emitters of black carbon. In contrast to the small portion of the mass it represents, Hendricks et al. (2004) estimated that the number of particles of $\mathrm{BC}$ produced from aircraft could represent more than $30 \%$ of the total particle numbers over a large part of the Northern Hemisphere free troposphere. Emissions from aircraft are concentrated in a latitude band from 20 to $50^{\circ} \mathrm{N}$ (Fig. 1). In terms of mass emitted from this sub-sector, there is a typical double maximum as a function of altitude: half of the emissions occur near the surface whereas the remaining half happens above an altitude of $6 \mathrm{~km}$. Black carbon emissions are assumed to be independent of altitude with an emission index of $4 \times 10^{-5} \mathrm{~kg} / \mathrm{kg}$ fuel (Döpelheuer, 2001). We infer a total global emission of BC from aircrafts of $5.3 \mathrm{GgC} \mathrm{yr}^{-1}$ for the fleet in 2000. In comparison, Hendricks et al. (2004) established a total global emission of BC from aircrafts of 4.7 $\mathrm{GgC} \mathrm{yr}^{-1}$ for the fleet of 1992 .

Baumgardner et al. (2004) report highly variable BC mass concentrations ranging from 0.2 to $1000 \mathrm{ng} \mathrm{m}^{-3}$ in the Arctic stratosphere. The contribution of BC emissions from aircraft alone could not explain the higher values of this range, hence tropospheric mid and high-latitude sources are likely to contribute significantly to these high concentrations measured over the Arctic.

The emissions of organic condensate from aviation are highly uncertain, Lee et al. (2009b) report a range for the emission factor from 0.0065 to $0.05 \mathrm{~g} / \mathrm{kg}$ fuel, using assumptions of constant particle diameter and a density of $1 \mathrm{~g} \mathrm{~cm}^{-3}$. We take the upper limit of this range to estimate maximum values for organic carbon produced from aircrafts (Table 1).

\subsection{Aerosol Module INCA-AER (Referred to as LSCE) and LMD radiation code}

The aerosol module INCA (Interactions between Aerosols and Chemistry) is coupled to the general circulation model, LMDz, developed at the Laboratoire de Météorologie Dynamique in Paris. The gas phase chemistry part is described by Hauglustaine et al. (2004). Aerosols and gases are treated in the same code to ensure coherence between gas phase chemistry and aerosol dynamics as well as possible interactions between gases and aerosol particles. The simulations described here were done with a horizontal resolution of $96 \times 72$ and the vertical direction was discretized into 19 layers. Each simulation lasted 14 months and the 2 first months were used as a spin-up period. INCA accounts for the following four basic properties of the ambient aerosol matter: size, chemical composition, hygroscopicity and mixing state of the particles.

The size of the aerosol is represented in INCA through a superposition of lognormal distributions. This multimodal approach allows the representation of the coexistence of externally and internally mixed particles with a limited number 
of tracers. In this work, we treat the sulphate and $\mathrm{OC}$ as external mixtures. Black carbon is considered either as externally mixed either or as internally mixed. In the case of internally mixed $\mathrm{BC}$, we follow the suggestion of Bond et al. (2006): increase the absorption for hydrophilic BC particles by $50 \%$ while no change is applied to hydrophobic BC particles. Submicron aerosols are transported into two distinct modes, one that is soluble (rather hygroscopic) and a second one that is insoluble.

The carbonaceous aerosol fraction is composed of various products of incomplete combustion of fossil fuels and biomass. Direct particle emissions contain both soot and organic matter. These substances are to a certain degree internally mixed and often difficult to separate in chemical analysis. However, the optical properties of the aerosol depend largely on the amount of $\mathrm{BC}$ that is present. Organic carbon was considered as a very weakly absorbing aerosol. In INCA, we keep track of both soluble and insoluble BC and POM. We assume that primary, insoluble carbonaceous particles become soluble with time. This ageing process transfers smaller size insoluble accumulation mode particles into the larger size soluble accumulation mode, decreasing slightly the mode diameter of the latter. The half life of ageing for $\mathrm{BC}$ and POM is taken as 1.1 days based upon Cooke and Wilson (1996). A ratio POM:OC=1.4:1 was used. This value corresponds to the low range of the values reported in Turpin et al. (1999).

The uptake and loss of water on aerosol particles (hygroscopicity) is generally fast and depends on the chemical composition, size and surface properties of the aerosol particle. Hygroscopic growth (HG) of aerosol particles is a major factor that determines the optical parameters of an aerosol population. Several attempts have been made to establish growth factors as a function of composition and size. Swietlicki et al. (1999) report many measurements where hydrophobic and hydrophilic particles coexisted.

In the case of an aerosol internally mixes, INCA takes into account the observation that two particles with different HG factors appear upon hydration of dry particles of a given diameter. This separation is represented through the two modes: a soluble one and an insoluble one. HG changes the particle diameter, the aerosol composition and particle surface characteristics. It is computed as a function of chemical composition in each mode. The parameterization follows initial ideas of Gerber's experimental work (Gerber, 1988). Gerber had established an approximate formula for aerosol growth behaviour of rural aerosol and sea salt. Our first assumption is that the hygroscopic growth of the ambient aerosol lies in between that of sea salt and of rural aerosol and is a linear function of the aerosol composition. In the case of an externally mixed aerosol, BC, OC and $\mathrm{SO}_{4}$ are then considered separately to determine their optical properties. The wet diameter of the aerosol is chosed to be the same as in the case of the internal mixtures, but optical properties of the individual components are determined from a look-up table which accounts for the ambient relative humidity in the model gridbox.

The solar radiation code in the LMDZ GCM consists of an improved version of the parameterizations of Fouquart and Bonnel (1980). The shortwave spectrum is divided into two intervals: $0.25-0.68$ and $0.68-4.00 \mu \mathrm{m}$, respectively. The model accounts for the diurnal cycle of solar radiation and allows fractional cloudiness to form in a grid box. The reflectivity and transmissivity of a layer are computed using the delta Eddington approximation (Joseph, 1996) in the case of a maximum random overlap (Morcrette and Fouquart, 1986) by averaging the clear and cloudy sky fluxes weighted linearly by their respective fractions in the layer. The radiative fluxes are computed every two hours, at the top-ofatmosphere and at the surface, with and without the presence of clouds, and with and without the presence of aerosols. The clear-sky and all-sky aerosol radiative forcings can then be estimated as the differences in radiative fluxes with and without aerosols.

\subsection{University of Reading (UREAD): radiation code}

The same aerosol mixing ratios calculated within the INCA aerosol module as described in the previous section are used here, therefore the state of mixing of the aerosol is treated in the same way as in INCA.

The radiative forcing due to the different aerosol types is calculated using the offline version of the radiation scheme that is used in the UK Met Office Unified Model (UM) by Edwards and Slingo (1996). The code is based on the twostream equations and uses the delta-Eddington approximation in the solar region of the spectrum. The spectral resolution in this code is variable. Six spectral bands in the shortwave part of the spectrum are used here. Rayleigh scattering and multiple scattering between cloud layers are included. Solar insolation is calculated as a function of latitude and day of the year (one calculation per month). The diurnal variation in the radiative forcing due to the variation of the solar zenith angle was taken into account by performing three calculations per half-day for zenith angles and then using Gaussian integration to produce the diurnal mean. The calculations are performed on a $3.75^{\circ} \times 2.5^{\circ}$ horizontal grid. The atmospheric profiles of temperature, vapour-, ozone-mixing ratios, as well as the surface albedo, are taken from a climatology constructed from a 50-year control run of the Unified Model. Cloud fraction and optical depths for high, medium and low clouds, were taken from the International Satellite Cloud Climatology Project climatology (Rossow and Schiffer, 1999). These clouds were inserted into the UM profiles at the closest vertical level, and random overlap between vertical levels was assumed. The algorithms used by this radiation code as well as the number of spectral bands (six compared to two in the LMDZ GCM) suggest that the UREAD code produces a more precise computation compared to the LMD radiation code described above. 
The model includes the scattering and absorption properties of aerosols via the specific extinction coefficient, the single scattering albedo, and the asymmetry factor. They were calculated using refractive indexes from Toon and Pollack (1976), in the case of ammonium sulphate and WCP (1986) for BC, a more detailed description on these calculations can be found in Haywood and Shine (1995). The optical properties for organic carbon are taken from the HadGEM2 version of the UM and are derived from biomass burning aerosols (N. Bellouin, personal communication, 2008). The lognormal size distribution has a radius of $0.12 \mu \mathrm{m}$ and a standard deviation of $0.13 \mu \mathrm{m}$. The real part of the refractive index is that of aged biomass burning, and the imaginary part is assumed to be wavelength independent at 0.006 . This leads to a single scattering albedo of about 0.97 at 0.55 micron. Hygroscopic growth factors are those of biomass-burning aerosols.

\subsection{Universtity of Oslo (UiO) Aerosol model and radiation code}

Oslo CTM2 is an off-line global aerosol and chemistry transport model that uses European Centre for Medium-Range Weather Forecasting (ECMWF) meteorological input data (Berglen et al., 2004; Isaksen et al., 2005; Myhre et al., 2009). The model includes a detailed chemistry scheme (Berntsen and Isaksen, 1997) and all main aerosol components such as mineral dust, sea salt, sulphate, nitrate, ammonium, black carbon, and primary as well as secondary organic carbon (Myhre et al., 2009). The meteorological data used in this study is from year 2003 and the model is run with a T42 horizontal resolution and 60 layers in the trosposphere and the stratosphere. A 2-months spinup period was used to allow the aerosol concentrations to reach quasi-equilibrium. The aerosol optical properties are calculated using Mie theory which involves information about aerosol size, refractive index, density, as well as aerosol hygroscopic growth; see Myhre et al. (2007) for more details. The carbonaceous particles are modelled as hydrophobic and hydrophilic particles with a conversion time of 2.5 days between these transported species based on Maria et al. (2004). The much longer conversion time than the 1.1 day used in the LSCE can explain the higher carbonaceous aerosols burdens for the $\mathrm{UiO}$ model compared to the ones obtained with the LSCE model. Oslo CTM2 has been compared to aerosol remote sensing results and ground based in situ measurements and radiative forcing of the direct aerosol effect over the industrial era for various aerosol components has been simulated (Myhre et al., 2009).

Bond and Bergstrom (2006) have made a critical assessment of the factors that influence the optical properties of $\mathrm{BC}$. In the simulations for this study we use size distributions, refractive index, and density so that the absorption coefficient is close to the recommended value from Bond and Bergstrom (2006) of $7.5 \mathrm{~m}^{2} \mathrm{~g}^{-1}$ for freshly emitted BC. Sensitivity tests have been performed for other choices of size distributions, refractive indices, and densities giving small impact on the radiative forcing due to BC (Myhre et al., 2009). However, it should be noted that a lower density or higher refractive index than recommended is necessary to derive the recommended absorption coefficient.

In this paper a lognormal size distribution with geometric radius of $0.0118 \mu \mathrm{m}$ and standard deviation of 2.0 was assumed for emitted BC particles. A test was done with a geometric radius of $0.04 \mu \mathrm{m}$ and standard deviation of 1.5 , the discussion of how it improves consistency can be found on page 1384 in Myhre et al. (2009).

Scattering aerosols are important as they enhance the absorption due to increased diffuse solar radiation (Stier et al., 2006) leading to an increase in the radiative forcing of nearly $10 \%$ in simulations of fossil fuel BC over the industrial era (Myhre et al., 2009). All the main aerosol components at their present abundances are included in the simulations of traffic related direct aerosol effect. For the radiative forcing calculations of organic carbon pure scattering aerosols are assumed and a ratio of $\mathrm{OM} / \mathrm{OC}$ of 1.6 is adopted.

The radiative forcing calculations in Oslo CTM 2 are performed with a multi-stream model using the discrete ordinate method (Stamnes et al., 1988). The radiative forcing is calculated at the top of the atmosphere with radiative transfer calculations every three hours.

\section{Radiative forcings}

Figure 2 shows the geographical distribution of the annualmean forcing for all three models for all three sectors, for the sum of all aerosol components. Figure 3 shows the zonalmean results and shows, in addition, the results for each aerosol component, Fig. 4 shows the corresponding globalmean results in the case of an internal mixture. Figure 5 shows the global-mean forcing for each sector with all the components summed together. It should be noted (see Fig. 2) that the advection of the aerosol components, and their precursors from their emission sources, means that the forcing over the oceans due to road traffic emissions, and the forcing over land due to shipping emissions can be substantial, especially in regions immediately downwind of areas of large emissions.

\subsection{Radiative forcing from the road sector}

Black carbon is the dominant contributor to the radiative forcing of aerosols emitted by road activities (Table 2, Figs. 3 and 4). All three models (Fig. 2) show maxima for the total (sum of BC, OC, and sulphate) direct aerosol effect at Northern mid-latitudes and also over North Africa and the Arabian Peninsula, regions with relatively low cloud-cover. Other regions where maxima occur are: Western and Central Europe, Eastern US, South Asia and Eastern China. Not surprisingly, these regions are also where the highest emissions take place (Fig. 1). 

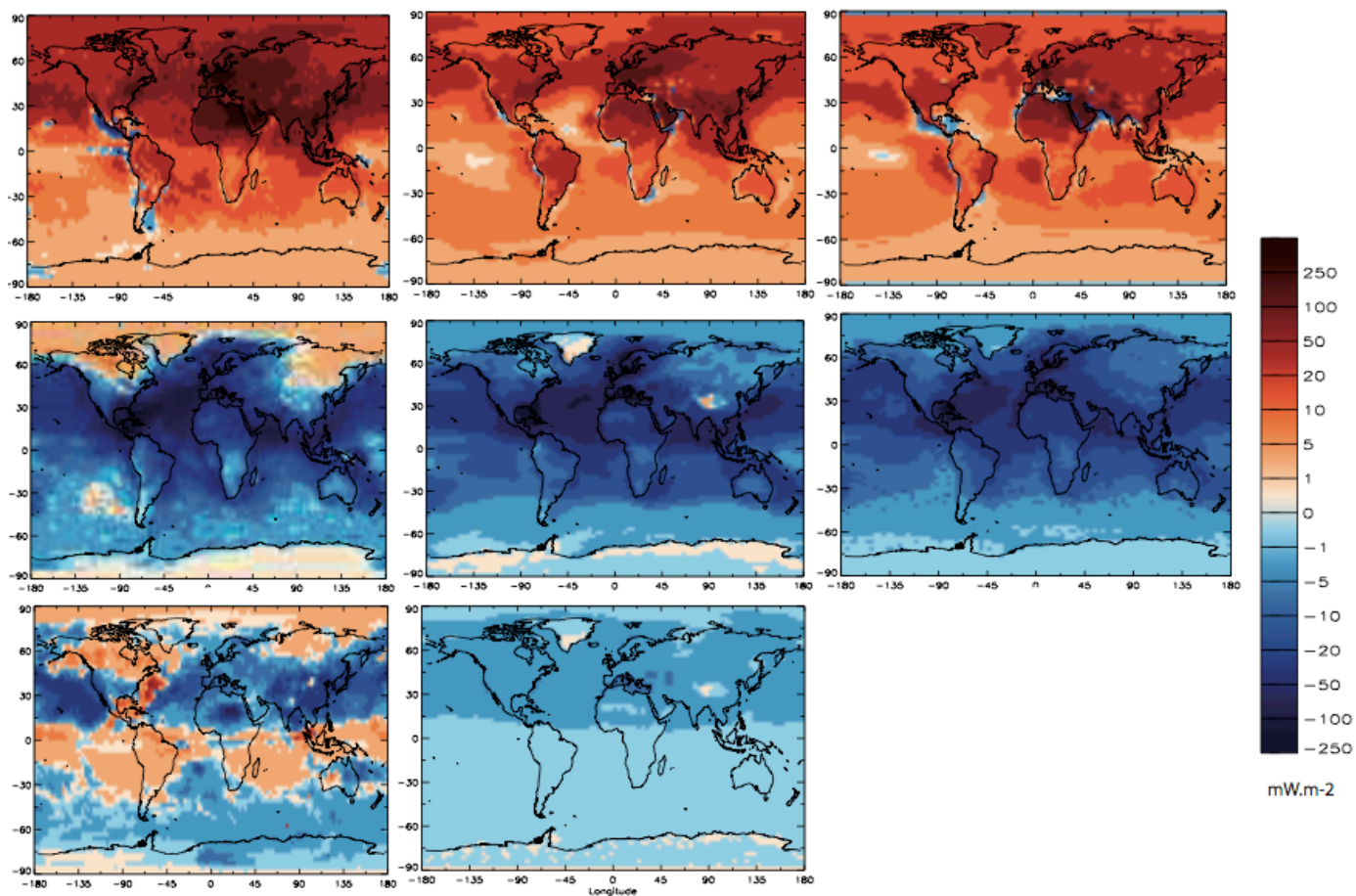

$\mathrm{mW} \cdot \mathrm{m}-2$

Fig. 2. All-sky radiative forcings $\left(\mathrm{mW} \mathrm{m}^{-2}\right)$ of the direct aerosol effect from the three models: UiO (left column), LSCE (middle column) and UREAD (right column). The first line represents the RF from road activities, the second line, RF from shipping and the third line RF from aviation. Radiative forcings from LSCE and UREAD radiation codes are shown for BC externally mixed with the other aerosol component, whereas for $\mathrm{UiO}$, radiative forcings are computed for $\mathrm{BC}$ internally mixed with other aerosol types.
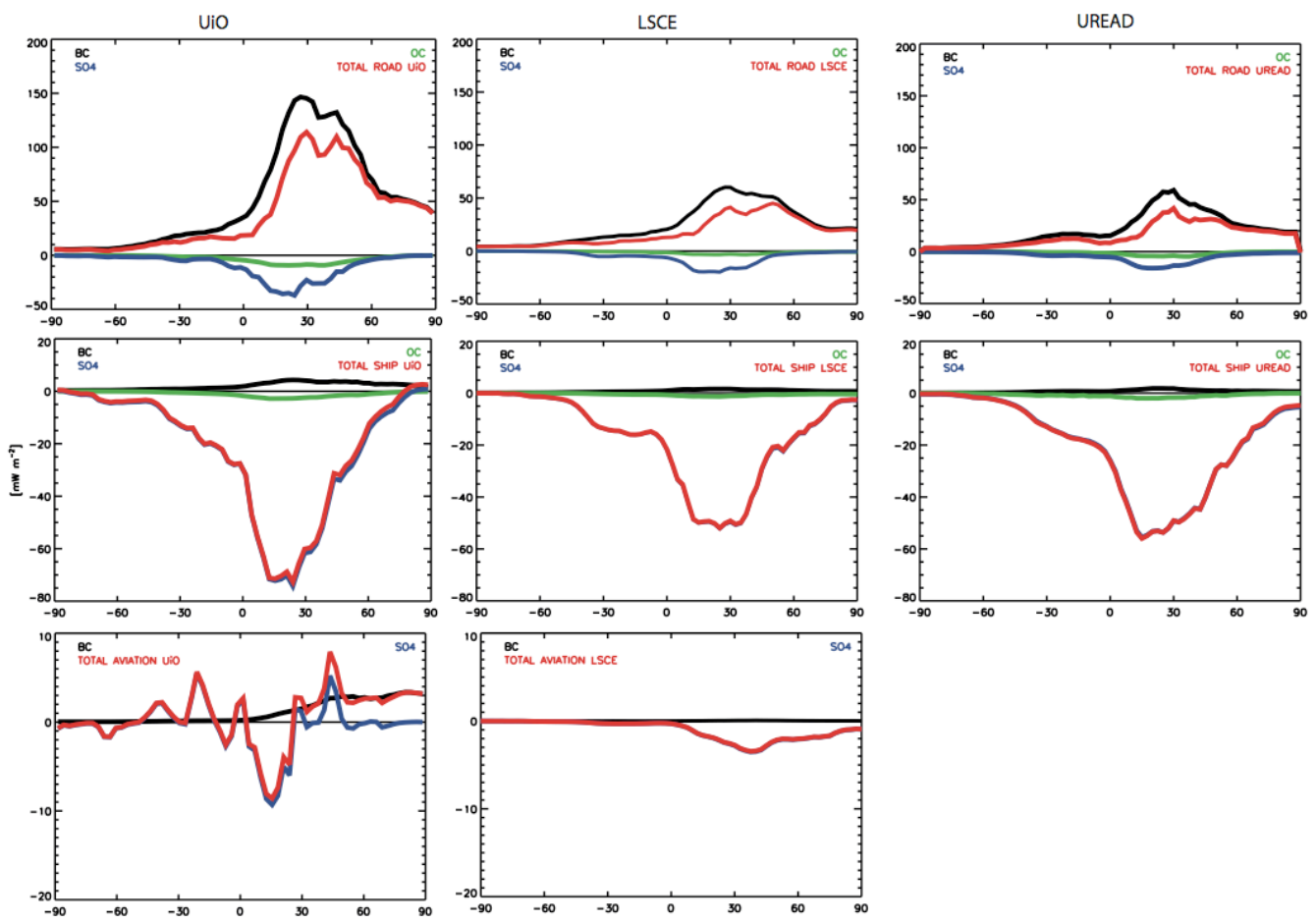

Fig. 3. Zonal-mean all-sky radiative forcings $\left(\mathrm{mW} \mathrm{m}^{-2}\right)$ of the direct aerosol effect from the three models. The panels are presented in the same order than in Fig. 2. As in Fig. 2, the radiative forcing from UiO model is presented for BC internally mixed with the other components of the aerosols, whereas the radiative forcings for LSCE and UREAD models are presented for an external mixture of aerosols. 
Table 2. Global-mean all-sky radiative forcing of the three aerosol components emitted from the road, ship and aviation sub-sectors. Radiative forcings are given for both an external and an internal mixture case.

\begin{tabular}{|c|c|c|c|c|c|c|}
\hline & \multicolumn{3}{|c|}{$\begin{array}{l}\text { Radiative Forcing }\left(\mathrm{mW} \mathrm{m}^{-2}\right) \\
\text { Case: External Mixture }\end{array}$} & \multicolumn{3}{|c|}{$\begin{array}{l}\text { Radiative Forcing }\left(\mathrm{mW} \mathrm{m}^{-2}\right) \\
\text { Case: Internal mixture }\end{array}$} \\
\hline & $\mathrm{UiO}$ & LSCE & UREAD & $\mathrm{UiO}$ & LSCE & UREAD \\
\hline \multicolumn{7}{|l|}{ ROAD subsector } \\
\hline $\mathrm{BC}$ & +44.0 & +26.6 & +24.4 & +57.6 & +38.0 & +34.9 \\
\hline OC & -4.0 & -1.5 & -1.8 & & & \\
\hline $\mathrm{SO}_{4}$ & -12.2 & -7.4 & -8.5 & & & \\
\hline Total: & +27.8 & +17.7 & +14.1 & +41.4 & +29.1 & +24.6 \\
\hline \multicolumn{7}{|l|}{ SHIPS subsector } \\
\hline $\mathrm{BC}$ & +1.7 & +0.9 & +0.9 & +2.2 & +1.3 & +1.3 \\
\hline $\mathrm{OC}$ & -1.3 & -0.6 & -1.0 & & & \\
\hline $\mathrm{SO}_{4}$ & -30.1 & -23.2 & -25.6 & & & \\
\hline Total: & -29.7 & -22.9 & -25.7 & -29.2 & -22.5 & -25.3 \\
\hline \multicolumn{7}{|c|}{ AVIATION subsector } \\
\hline $\mathrm{BC}$ & +0.7 & +0.04 & +0.04 & +0.9 & +0.06 & +0.06 \\
\hline $\mathrm{OC}$ & & gligible & & & & \\
\hline $\mathrm{SO}_{4}$ & -0.6 & -1.1 & & & & \\
\hline Total $\left(\mathrm{BC}+\mathrm{SO}_{4}\right)$ : & +0.1 & -1.1 & & +0.3 & -1.0 & \\
\hline
\end{tabular}

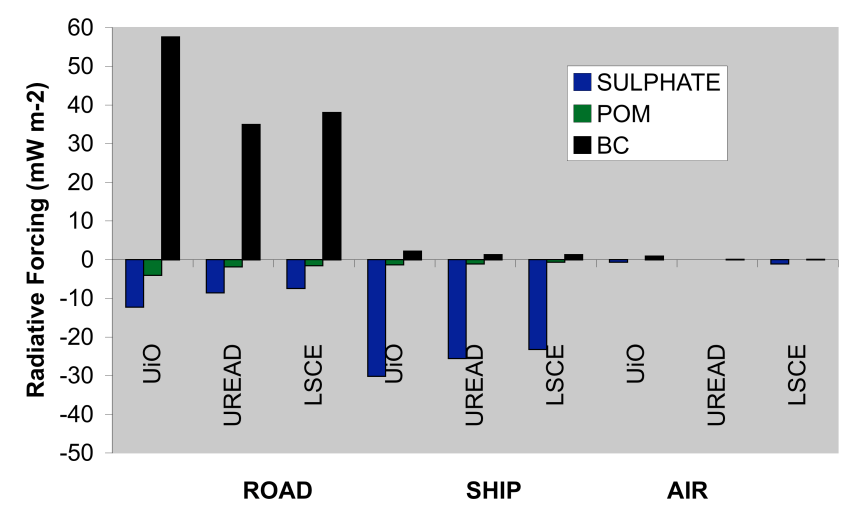

Fig. 4. Global-mean all-sky direct aerosol radiative forcings $\left(\mathrm{mW} \mathrm{m}^{-2}\right)$ by subsectors and for each of the three aerosol components: $\mathrm{BC}, \mathrm{OC}$ and SO4. The results are presented for the three models. For all models, the BC aerosols are considered internally mixed.

\subsubsection{Externally mixed aerosols}

The average net radiative forcings from the three aerosol components (BC, OC and sulphate) considered as an external mixture, amount respectively to: $+14.1,+17.7$ and $+27.8 \mathrm{~mW} \mathrm{~m}^{-2}$ in the three radiation codes, respectively: UREAD, LSCE (Laboratoire des Sciences du Climat et de l'Environnement) and UiO.

The much higher value obtained in the case of the UiO model can mainly be explained by the higher burden as shown in the normalized radiative forcing in Table 3. The higher burden in the $\mathrm{UiO}$ model is to a large degree

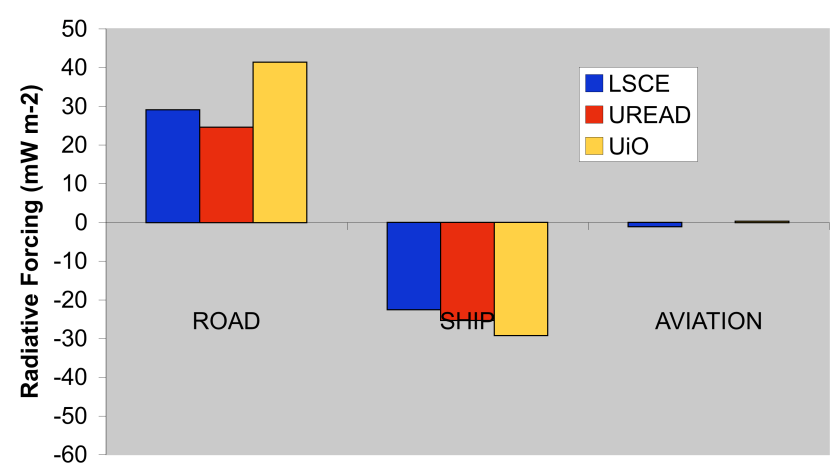

Fig. 5. Comparison of the all-sky total direct aerosol global-mean radiative forcings $\left(\mathrm{mW} \mathrm{m}^{-2}\right)$ for the three sub-sectors. For all three models, the $\mathrm{BC}$ aerosols are considered internally mixed.

due to the extended lifetime of hydrophobic particles based upon measurements reported in Maria et al. (2004). The absorption and total extinction used in the three models agrees within $10 \%$ as shown in Table 3 and the variation in the normalized radiative forcing is much smaller than what is typical between various global aerosol models (Schulz et al., 2006).

\subsubsection{Internally mixed aerosols}

As noted in Sect. 2.6, the UiO model includes both internal aerosol mixtures and the effect of enhanced absorption due to the extra diffuse radiation scattered from other aerosol components. 
Table 3. Burden, AOD and RF for BC for the 3 MODELS. Absorption and total extinction at $550 \mathrm{~nm}$ is given. Normalized RF is given as the all-sky radiative forcing (external mixing for all three models) divided by the burden.

\begin{tabular}{|c|c|c|c|c|c|c|c|}
\hline & $\begin{array}{l}\text { BC Col. Load } \\
\left(\mathrm{mg} \mathrm{m}^{-2}\right)\end{array}$ & $\begin{array}{l}\text { Abs. } \\
\text { Extinction } \\
\left(\mathrm{m}^{2} \mathrm{~kg}^{-1}\right)\end{array}$ & $\begin{array}{l}\text { Total } \\
\text { Extinction } \\
\left(\mathrm{m}^{2} \mathrm{~kg}^{-1}\right)\end{array}$ & $\begin{array}{l}\text { AOD } \\
\left.\text { @ } 550 \mathrm{~nm}^{-2}\right) \\
\left(\mathrm{mW} \mathrm{m}^{-2}\right)\end{array}$ & $\begin{array}{l}\text { RF External } \\
\left(\mathrm{mW} \mathrm{m}^{-2}\right)\end{array}$ & $\begin{array}{l}\text { RF Internal } \\
\left(\mathrm{W} \mathrm{g}^{-1}\right)\end{array}$ & $\begin{array}{l}\text { Normalized } \\
\text { External RF }\end{array}$ \\
\hline UiO OSLO & & 7320 & 9240 & & & & \\
\hline BC Road & 0.0309 & & & $3.60 \times 10^{-4}$ & +44.0 & +57.6 & 1430 \\
\hline BC Ships & 0.00122 & & & $1.45 \times 10^{-5}$ & +1.7 & +2.2 & 1390 \\
\hline BC Aviation & 0.000302 & & & $3.76 \times 10^{-6}$ & +0.7 & +0.9 & 2320 \\
\hline LSCE GIF/Yvette & & & 9740 & & & & \\
\hline BC Road & 0.0189 & & & $1.84 \times 10^{-4}$ & +26.6 & +38.0 & 1410 \\
\hline BC Ships & 0.00079 & & & $8.0 \times 10^{-6}$ & +0.9 & +1.3 & 1140 \\
\hline BC Aviation & 0.00003 & & & $1.9 \times 10^{-7}$ & +0.04 & +0.06 & 1500 \\
\hline UREAD READING & & 7990 & 11900 & & & & \\
\hline BC Road & 0.0203 & & & $2.42 \times 10^{-4}$ & +24.4 & +34.9 & 1200 \\
\hline BC Ships & 0.00083 & & & $9.83 \times 10^{-5}$ & +0.9 & +1.3 & 1080 \\
\hline BC Aviation & 0.00004 & & & $3.42 \times 10^{-7}$ & +0.04 & +0.06 & 1000 \\
\hline
\end{tabular}

Measurements of the size of particles emitted from vehicles that use either diesel or gasoline has been reviewed by Bond et al. (2006b, Table 3). For diesel, the studies cited report particle sizes with count mean diameter that range between 22 and $120 \mathrm{~nm}$. For gasoline powered vehicles, the size of particle emitted measured at the tailpipe is reported to range from 18 to $150 \mathrm{~nm}$. The absorption amplification is defined by Bond et al. (2006b) as the ratio of absorption by a mixed particle to absorption by a pure particle when both particles contain the same amount of light-absorbing carbon mass. It ranges from 1.15 to 2.5 for particles with these sizes in the case of small size shells. Particles in plumes away from sources have grown to diameters larger than $110 \mathrm{~nm}$ through condensation and coagulation processes. For particles in these size ranges, particle amplification ranges from 1.0 to 2.5 , only in the range $110-150 \mathrm{~nm}$ absorption amplification can reach 3.0. In the case of a wide size distribution, the absorption amplification grows to a maximum of 1.9. Based upon their results, Bond et al. (2006b) suggested a simplified approach for models that consider hydrophilic and hydrophobic particles separately. For hydrophilic particles, it is suggested to increase of the absorption by $50 \%$ but not to increase it for fresh BC particles. This approach leads to an increase in the radiative forcing by $31 \%$ for the road sector in global calculations of the UiO model and $43 \%$ in the LSCE or UREAD model that have the same assumptions concerning the partitioning between soluble and insoluble BC (see right hand columns of Table 2).

Table 2 and Fig. 4 present the global-mean radiative forcings for the 3 models and for all components (BC, OC and $\mathrm{SO}_{4}$ ) produced from transportation. The internally mixed hypothesis leads to an estimate for radiative forcing from $\mathrm{BC}$ of $+57.6,38.0$ and $34.9 \mathrm{~mW} \mathrm{~m}^{-2}$ for the UiO, LSCE and UREAD models, respectively. The difference between the
UiO model and the two others is to a large part due to the higher burden of BC assumed (longer lifetime for the hydrophobic fraction). For this case the normalized radiative forcing is quite similar (not shown).

Compared to $\mathrm{OC}$ and $\mathrm{SO}_{4}, \mathrm{BC}$ dominates the radiative forcing from the road sector. The combination of $\mathrm{OC}$ and $\mathrm{SO}_{4}$ in all three models accounts for -9 to $-16 \mathrm{~mW} \mathrm{~m}^{-2}$.

\subsubsection{Comparison with previously published results}

Köhler et al. (2001), with emissions of BC from roads that are 3 times the inventory from Borken et al. (2007), did a rough calculation based upon a simplified description of the $\mathrm{BC}$ cycle. They estimated a direct radiative forcing for $\mathrm{BC}$ of $80 \mathrm{~mW} \mathrm{~m}^{-2}$. If we scale the amount of black carbon that is used by these authors to that used in the present study, the direct forcing obtained is $27 \mathrm{~mW} \mathrm{~m}^{-2}$ in good agreement with the results presented here for the external mixture. In Table 7 of Schultz et al. (2004), the combined direct and indirect effect of $\mathrm{BC}$ of 64 to $160 \mathrm{~mW} \mathrm{~m}^{-2}$ is reported. The atmospheric load of BC from road traffic $\left(52.9 \times 10^{-6} \mathrm{~g} \mathrm{~m}^{-2}\right)$ is to 2.8 times greater than estimated in this work. The normalised forcings from the three models in Table 3 (1200 to $1430 \mathrm{~W} \mathrm{~g}^{-1}$ ) are in the low range of the ones reported by Schultz et al. (2004) (1210 to $3100 \mathrm{~W} \mathrm{~g}^{-1}$ ). The radiative forcing for OC in this study is substantially weaker than in Fuglestvedt et al. (2008). The mean estimate for BC (external mixture) in this study is stronger than in Fuglestvedt et al. (2008). Fuglestvedt et al. (2008) compared the UiO model results to previous results from the literature and estimated a range of the radiative forcing of $\mathrm{BC}$ from road activities. This estimated range is from 14 to $32 \mathrm{~mW} \mathrm{~m}^{-2}$ (Table 4). The results reported here indicate higher values from 24.4 to $57.6 \mathrm{~mW} \mathrm{~m}^{-2}$ when both externally and internally mixed BC are considered. More recently, Unger et al. (2010) used the 
Table 4. Mean direct radiative forcings and standard deviation $\left(\mathrm{mW} \mathrm{m}^{-2}\right)$ computed in this study together with the values reported by Fuglestvedt et al. (2008) associated with estimated uncertainties.

\begin{tabular}{|c|c|c|c|c|}
\hline & $\begin{array}{c}\text { This study, } \\
\text { External mixture } \\
\text { (Mean value } \pm \text { Std Deviation) }\end{array}$ & $\begin{array}{l}\text { This study } \\
\text { Internal mixture }\end{array}$ & $\begin{array}{c}\text { Ranges* reported in } \\
\text { Fuglestvedt et al. (2008) }\end{array}$ & $\begin{array}{l}\text { Values reported in } \\
\text { Unger et al. (Table S2, 2010) }\end{array}$ \\
\hline $\begin{array}{l}\text { ROAD subsector } \\
\mathrm{BC} \\
\mathrm{OC} \\
\mathrm{SO}_{4} \\
\text { Total aerosols } \\
\mathrm{GHG}^{* *}\end{array}$ & $\begin{array}{c}+31.7 \pm 10.7 \\
-2.4 \pm 1.4 \\
-9.4 \pm 2.5 \\
+19.9 \pm 11.1\end{array}$ & $\begin{array}{l}+43.5 \pm 12.3 \\
+31.7 \pm 12.6\end{array}$ & $\begin{array}{c}+23 \pm 9 \\
-8 \pm 4 \\
-12 \pm 5 \\
+3 \pm 11 \\
+192 \pm 26\end{array}$ & $\begin{array}{l}+71 \\
-16 \\
-14 \\
+41\end{array}$ \\
\hline $\begin{array}{l}\text { SHIPS subsector } \\
\mathrm{BC} \\
\mathrm{OC} \\
\mathrm{SO}_{4} \\
\text { Total aerosols } \\
\text { GHG }\end{array}$ & $\begin{array}{c}+1.1 \pm 0.5 \\
-1.0 \pm 0.4 \\
-26.3 \pm 3.5 \\
-26.1 \pm 3.6\end{array}$ & $\begin{array}{l}+1.6 \pm 0.5 \\
-25.7 \pm 3.6\end{array}$ & $\begin{array}{c}2.0 \pm 0.9 \\
-0.3 \pm 0.2 \\
-47 \text { to }-16 \\
-46 \text { to }-13 \\
+24 \pm 17\end{array}$ & $\begin{array}{l}+3 \\
-3 \\
-16 \\
-16\end{array}$ \\
\hline $\begin{array}{l}\text { AVIATION subsector } \\
\mathrm{BC} \\
\mathrm{OC} \\
\mathrm{SO}_{4} \\
\text { Total }\left(\mathrm{BC}+\mathrm{SO}_{4}\right): \\
\text { GHG }\end{array}$ & $\begin{array}{c}+0.3 \pm 0.4 \\
\text { Negligible } \\
-0.9 \pm 0.4 \\
-0.3 \pm 0.6\end{array}$ & $\begin{array}{l}+0.3 \pm 0.5 \\
-0.3 \pm 0.6\end{array}$ & $\begin{array}{c}0.1 \pm 0.03 \\
-0.01 \pm 0.01 \\
-11 \text { to }-2 \\
-11 \text { to }-2 \\
+31 \pm 31\end{array}$ & $\begin{array}{l}+3 \\
+1 \\
-16 \\
-13\end{array}$ \\
\hline
\end{tabular}

* The ranges reported here were obtained through Monte Carlo simulations that included uncertainties in emissions (see Table 3 of the Supplementary Material in Fuglestvedt et al., 2008).

** GHG stands for the effect of the following greenhouse gases: $\mathrm{CO}_{2}$, ozone and $\mathrm{CH}_{4}$ lifetime as best estimates from Fuglestvedt et al. (2008), Supplementary Information, Table 5.

Fast track inventory for on-road and off-road transport. The $\mathrm{BC}$ emissions from on-road traffic in this inventory amounts to $1235 \mathrm{Ktons}^{-1}$ and the corresponding radiative forcing is estimated in this work to be $71 \mathrm{~mW} \mathrm{~m}^{-2}$. By comparison, the present work uses the QUANTIFY based estimate of onroad emissions is $722 \mathrm{Ktons} \mathrm{yr}^{-1}$ and the radiative forcing for BC internally mixed is $44 \mathrm{~mW} \mathrm{~m}^{-2}$ (Table 3 ). Koch et al. (2007) also report the contribution of sectors to aerosol direct. Radiative forcings for $\mathrm{BC}$ for all transport sectors combined amount to $56 \mathrm{~mW} \mathrm{~m}^{-2}$.

\subsection{Radiative forcing from the ship sector}

The radiative forcing from sulphate produced from shipping activities overwhelms the forcings from the two other components: BC and OC (see Table 2 and Fig. 4). This is also true for aerosol loads and optical depth (Table 1). The overall effect of the three aerosol components (sulphate, BC and OC) is largely dominated by sulphate as the sum of BC and OC contribution does not exceed $1 \mathrm{~mW} \mathrm{~m}^{-2}$ in any of the 3 models. The combined radiative forcing from the sum of sulphate, $\mathrm{BC}$ and $\mathrm{OC}$ produced by shipping emissions is dominated by the negative sulphate contribution. The geographical distribution of aerosol concentrations which are predominant over oceanic surfaces with a low albedo, also reinforces this negative raditive forcing. Only over surfaces with very high albedos (snow- and ice-covered regions) does this forcing have a positive sign. In Fig. 2, aerosols are treated as externally mixed for the LSCE and UREAD models, whereas BC is internally mixed with other aerosols in the case of the UiO model. When aerosols are treated as an internal mixture, most of the areas that are covered with snow for more than 6 months of the year, exert a positive forcing (Fig. 2). Areas that are particularly affected by aerosols from shipping activities are: the North Sea, the western coasts of Europe, the Mediterranean, the tropical Atlantic and the northern Indian Ocean. The global-mean sulphate radiative forcings from the three models are: $-30.1,-23.2$ and $-25.6 \mathrm{~mW} \mathrm{~m}^{-2}$ (see Table 2).

\subsubsection{Comparison with previously published results}

Lauer et al. (2007) estimated the direct radiative forcing from sulphate, nitrates, ammonium and associated liquid water at the Top-of-Atmosphere (ToA) from the three shipping inventories they used to range between -11 to $-13 \mathrm{~mW} \mathrm{~m}^{-2}$ under all-sky conditions. Fuglestvedt et al. (2008) compared UiO model results to previous results from the literature came up with a range from the ship sector that span from -46 to $-13 \mathrm{~mW} \mathrm{~m}^{-2}$. The range we report here is 
much narrower. The total direct aerosol radiative forcings from shipping activities obtained in this work are respectively: $-30,-23$ and $-26 \mathrm{~mW} \mathrm{~m}^{-2}$ for the three radiation codes. This narrower range could come from the use of a single emission inventory.

\subsection{Radiative forcing from the aviation sector}

The radiative forcing from the aviation sector shows the highest contrast between the two cases when the aerosol components are treated as an internal or external mixture. The internal mixture with the $\mathrm{BC}$ as the core and the $\mathrm{SO}_{4}$ as a shell is an efficient absorber and shows prominent areas with positive forcings not only over regions that are snow covered but also between the Equator and around $30^{\circ} \mathrm{S}$ (Fig. 2).

In this work the contribution of the sum of $\mathrm{BC}$ and $\mathrm{SO}_{4}$ to the radiative forcing from aviation is respectively +0.1 and $-1.1 \mathrm{~mW} \mathrm{~m}^{-2}$ for the case of BC externally mixed and +0.3 to $-1.0 \mathrm{~mW} \mathrm{~m}^{-2}$ when $\mathrm{BC}$ is considered internally mixed with sulphate. For these estimates, the two radiation codes from UiO and LSCE were used.

The work of Danilin et al. (1998) presents one of the first estimates of radiative forcing from soot and sulphur emitted from aircraft. In that paper, eleven models were intercompared in an aircraft fuel tracer simulation based upon a 1992 inventory. The authors derived upper limits for stratospheric $\mathrm{H}_{2} \mathrm{O}$ build-up from aircraft as well as aviation induced aerosol loads. As reported in IPCC (1999) this work led to an estimate of the radiative forcing of $\mathrm{BC}$ from aircraft emissions for the year 1992 in the range of 1 to $6 \mathrm{~mW} \mathrm{~m}^{-2}$.

For sulphate, all the sulphur produced is converted to sulphate and the emission factor is $4 \times 10^{-4} \mathrm{kgS}(\mathrm{kg} \text { fuel })^{-1}$. Kjellström et al. (1999) point out that the contribution of aircraft sulphate to the total burden is less than $1 \%(0.16 \%$ in their work and $0.30 \%$ in our simulation). The radiative forcing of the direct aerosol effect from the aviation sector is less negative in this study compared to Fuglestvedt et al. (2008). It agrees with the mean value reported from the project TRADEOFF reported in Lee (2004).

\section{Conclusions}

We have computed the radiative forcings of aerosol from road, ship and aviation transport using two different aerosol models (LSCE and UiO) and three different radiation codes (LSCE, UREAD and UiO). The differences between the forcings from these models originate from their treatment of the aerosol cycle, the assumptions about aerosol component mixing and probably from differences between the respective radiation codes, e.g. such as the methods of calculating both single and multiple scattering and the number of spectral bands (see e.g. Schulz et al., 2006).

For the road subsector, the net direct radiative forcing is dominated by the black carbon component that accounts for a much larger fraction of the total forcing than either $\mathrm{OC}$ or $\mathrm{SO}_{4}$ (Fig. 4). When $\mathrm{BC}$ is internally mixed with the other aerosol components, $\mathrm{RF}$ for the sum of $\mathrm{BC}, \mathrm{POM}$ and $\mathrm{SO}_{4}$ ranges from +24.6 to $+41.4 \mathrm{~mW} \mathrm{~m}^{-2}$ for the three radiation codes, whereas when the aerosols are considered externally mixed, RF ranges from +14.1 to $+27.8 \mathrm{~mW} \mathrm{~m}^{-2}$. Based upon the black carbon property reported in the literature, the radiative forcing from road transport is more likely to be represented by the higher net forcing reported for the case of the internal mixture. This higher value is due to the following property: the enhanced $\mathrm{BC}$ absorption when a shell of scattering material $\left(\mathrm{OC}\right.$ and $\left.\mathrm{SO}_{4}\right)$ is present (Bond et al., 2006; Fuller et al., 1999; Haywood and Shine, 1995). For internally mixed aerosols, the net direct radiative forcing from the road sector represents 13 to $21 \%$ of the radiative forcing due to greenhouse gases $\left(\mathrm{CO}_{2}, \mathrm{O}_{3}\right.$ and $\mathrm{CH}_{4}$ lifetime) which adds up to $192 \mathrm{~mW} \mathrm{~m}^{-2}$ (see Table 5 from Supplementary Information from Fuglestvedt et al., 2008).

In the case of shipping, the net direct aerosol radiative forcing is negative (Fig. 4). This forcing is dominated by the contribution of the sulphate component of the aerosol; the small contributions of $\mathrm{OC}$ and $\mathrm{BC}$ tend to compensate each other. For an internal or an external mixture, the radiative forcings from shipping range from -30 to $-23 \mathrm{~mW} \mathrm{~m}^{-2}$ and hence is only slightly dependent on the mixing assumption. The small differences between these results are attributable partly to differences in burden and extinction coefficients for sulfate (which can differ by the treatments of hygroscopic growth that differ in the models), and probably partly to the details of the radiation codes. The small difference between internal and external mixtures is attributable to the fact that for shipping sulphate dominates, where mixing assumptions is thought to be of smaller importance. All models show a positive global and annual mean radiative forcing of the total direct aerosol effect for the road transport sector and a negative radiative forcing for the shipping sector (Fig. 5). This result is independent of the mixing assumption of $\mathrm{BC}$, which is shown to impact the magnitude of the radiative forcing.

For aviation, the net radiative forcing is much smaller compared to the two other subsectors (Fig. 4). Sulphate and $\mathrm{BC}$ have opposite contributions to the radiative forcing that can cancel each other (Figs. 3 and 4). For an external mixture, we find a net RF for the LSCE and UiO models of respectively, -1.1 to $+0.1 \mathrm{~mW} \mathrm{~m}^{-2}$ whereas for internal mixture these RF from aviation are -1.0 and $+0.3 \mathrm{~mW} \mathrm{~m}^{-2}$. The emissions of aerosols and their precursors from aviation are much smaller than from the two other transport sectors and thus the radiative forcing is weak.

These main findings are consistent with results in the only multicomponent model study of the different transport sectors (Fuglestvedt et al., 2008). They add the following information compared to the results that are summarized in $\mathrm{Fu}$ glestvedt et al. (2008):

- the positive direct forcing of aerosols from the road sector $\left(+20 \pm 11 \mathrm{~mW} \mathrm{~m}^{-2}\right.$ for an externally mixed case, and $+32 \pm 13 \mathrm{~mW} \mathrm{~m}^{-2}$ when $\mathrm{BC}$ is considered internally 
mixed) is much stronger than the previous estimate suggested $\left(+3 \pm 11 \mathrm{~mW} \mathrm{~m}^{-2}\right)$.

- This study indicates that the direct effect of aerosols produced from shipping activities is better constrained than previously estimated.

- The direct radiative effect of aerosols from aviation is small compared to the aerosols produced from road and ship activities.

Acknowledgements. This work is funded by the European Commissions FP6 integrated project, QUANTIFY. We thank Nicola Stuber and Jan Fuglestvedt for valuable discussions and help with processing the data.

\section{Edited by: M. Kanakidou}

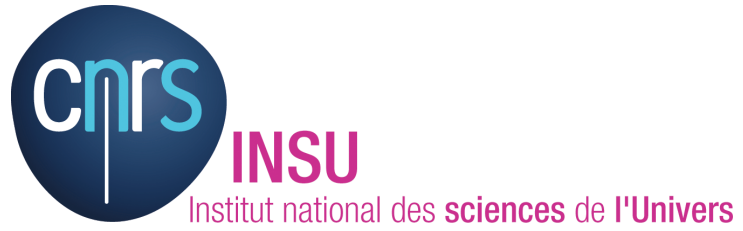

The publication of this article is financed by CNRS-INSU.

\section{References}

Baumgardner, D., Kok, G., and Raga, G.: Warming of the Arctic lower stratosphere by light absorbing particles, Geophys. Res. Lett., 31, L06117, doi:10.1029/2003GL018883, 2004.

Berglen, T. F., Berntsen, T. K., Isaksen, I. S. A., and Sundet, J. K.: A global model of the coupled sulfur/oxidant chemistry in the troposphere: The sulfur cycle, J. Geophys. Res., 109(D19), D19310, doi:10.1029/2003JD003948, 2004.

Berntsen, T. K. and Isaksen, I. S. A.: A global three-dimensional chemical transport model for the troposphere. 1. Model description and CO and ozone results, J. Geophys. Res., 102(D17), 21239-21280, 1997.

Bond, T. C., Streets, D. G., Yarber, K. F., Nelson, S. M., Woo, J.-H., and Klimont, Z.: A Technology-Based Global Inventory of Black and Organic Carbon Emissions from Combustion, J. Geophys. Res., 109, D14203, doi:10.1029/2003JD003697, 2004.

Bond, T. C. and R. W. Bergstrom, Light Absorption by Carbonaceous Particles: An Investigative Review, Aerosol Sci. Technol., 40, 27-67, 2006a.

Bond, T. C., Habib, G., and Bergstrom, R. W.: Limitations in the enhancement of visible light absorption due to mixing state, J. Geophys. Res., 111(D20), D20211, doi:10.1029/2006JD007315, 2006b.

Borken, J., Steller, H., Meretei, T., and Vanhove, F.: Global and country inventory of road passenger and freight transportation: Fuel consumption and emissions of air pollutants in the year 2000, in: Transportation Research Records - Journal of the Transportation Research Board, 2011, 127-136, doi:10.3141/2011-14, ISSN 0361-1981, 2007.
Capaldo, K., Corbett, J. J., Kasibhatla, P., Fischbeck, P., and Pandis, S. N.: Is aerosol production within the remote marine boundary layer sufficient to maintain observed concentrations?, Nature, 400, 743-746, 1999.

Cheng, Y. F., Eichler, H., Wiedensohler, A., et al.: Mixing state of elemental carbon and non-light-absorbing aerosol components derived from in situ particle optical properties at Xinken in Pearl River Delta of China, J. Geophys. Res., 111(D20), D20204, doi:10.1029/2005JD006929, 2006.

Corbett, J. J. and Köhler, H. W.: Updated emissions from ocean shipping, J. Geophys. Res., 108(D20), 4650, doi:10.1029/2003JD003751, 2003.

Cooke, W. F. and Wilson, J. J. N.: A global black carbon aerosol model, J. Geophys. Res., 101, 19395-19409, 1996.

Danilin, M. Y., Fahey, D. W., Schumann, U., et al.: Aviation fuel tracer simulation: Model intercomparison and implications, Geophys. Res. Lett., 25, 3947-3950, 1998.

Döpelheuer, SAE Paper No 2001-01-3008, Proceedings of the 2001 Aerospace Congress, 10-14 September, 2001.

Edwards, J. M. and Slingo, A.: Studies with a flexible new radiation code I. Choosing a configuration for a large-scale model, Q. J. Roy. Meteor. Soc., 122, 689-719, 1996.

Endresen, Ø., Bakke, J., Sørgård, E., Berglen, T. F., and Holmvang, P.: Improved modelling of ship $\mathrm{SO}_{2}$ emissions - A fuel based approach, Atmos. Environ., 39, 3621-3628, 2005.

Endresen, Ø., Sørgård, E., Behrens, H. L., Brett, P. O., and Isaksen, I. S. A.: A historical reconstruction of ships fuel consumption and emissions, J. Geophys. Res., 112, D12301, doi:10.1029/2006JD007630, 2007.

Eyring, V., Kohler, H. W., van Aardenne, J., and Lauer, A.: Emissions from international shipping: 1. The last 50 years, J. Geophys. Res., 110, D17305, doi:10.1029/2004JD005619, 2005.

Fuglestvedt, J., Berntsen, T., Myhre, G., Rypdal, K., and Skeie, R. B.: Climate forcing from the transport sectors, Proc. Natl. Acad. Sci. USA, 105(2), 454-458, 2008.

Fuller, K. A., W. C. Malm, S. M. Kreidenweis, Effects of mixing on extinction by carbonaceous particles, J. Geophys. Res., 104(D13), 15941-15954, 20 July, 1999.

Gerber, H. E.: Atmospheric Aerosols and Nucleation, in: Lecture Notes Physics, New York, USA, 237-238, 1988.

Hara, K., Yamagata, S., Yamanouchi, T., Sato, K., Herber, A., et al.: Mixing states of individual aerosol particles in spring Arctic troposphere during ASTAR 2000 campaign, J. Geophys. Res., 108(D7), 4209, doi:10.1029/2002JD002513, 2003.

Hauglustaine, D. A., Hourdin, F., Walters, S., Jourdain, L., Filiberti, M.-A., Larmarque, J.-F., and Holland, E. A.: Interactive chemistry in the Laboratoire de Météorologie Dynamique general circulation model : description and background tropospheric chemistry evaluation, J. Geophys. Res., 109, D04314, doi:10.1029/2003JD003957, 2004.

Haywood, J. M., and Shine, K. P.: The effect of anthropogenic sulfate and soot aerosol on the clear sky planetary radiation budget Geophys. Res. Lett., 22(5), 603-606, 1995.

Hendricks, J., Kärcher, B., Döpelheuer, A., Feichter, J., Lohmann, U., and Baumgardner, D.: Simulating the global atmospheric black carbon cycle: a revisit to the contribution of aircraft emissions, Atmos. Chem. Phys., 4, 2521-2541, 2004.

IEA (International Energy Agency): Oil Information 2006, Table 9 , International Energy Agency, Paris, France, 749 pp., 2007. 
Isaksen, I. S. A., Zerefos, C., Kourtidis, K., Meleti, C., Dalsoren, S. B., et al.: Tropospheric ozone changes at unpolluted and semipolluted regions induced by stratospheric ozone changes, J. Geophys. Res., 110, D02302, doi:10.1029/2004JD004618, 2005.

Joseph, J. H., Wiscombe, W. J., and Weinman, J. A.: The deltaEddington approximation for radiative flux transfer, J. Atmos. Sci., 33, 2452-2459, 1996.

Koch, D., Bond, T. C., Streets, D., Unger, N., and van der Werf, G. R.: Global impacts of aerosols from particular source regions and sectors, J. Geophys. Res., 112, D02205, doi:10.1029/2005JD007024, 2007.

Kjellström, E., Feichter, J., Sausen, R., and Hein, R.: The contribution of aircraft emissions to the atmospheric sulfur budget, Atmos. Environ., 33, 3455-3465, 1999.

Köhler, I., Dameris, M., Ackerman, I., and Hass, H.: Contribution of road traffic emissions to the atmospheric black carbon burden in the mid-1990s, J. Geophys. Res., 106, 17997-18014, 2001.

Lauer, A., Eyring, V., Hendricks, J., Jckel, P., and Lohmann, U.: Global model simulations of the impact of ocean-going ships on aerosols, clouds, and the radiation budget, Atmos. Chem. Phys., 7, 5061-5079, doi:10.5194/acp-7-5061-2007, 2007.

Lee, D. S.: The impact of aviation on climate, in: Issues in Environmental Science and Technology, ransport and the environment, 20, 1-23, ISSN 1350-7583, 2004.

Lee D. S., Fahey, D. W., Forster, P. M., et al.: Aviation and global climate change in the 21st century, Atmos. Environ., 43(22-23), 3520-3537, 2009a.

Lee, D. S., Pitari, G., Grewe, V., et al.: Transport impacts on atmosphere and climate: Aviation, Atmos. Environ., doi:10.1016/j.atmosenv.2009.06.005, in press, 2009b.

Mallet, M., Roger, J. C., Despiau, S., Putaud, J. P., and Dubovik, O.: A study of the mixing state of black carbon in urban zone, J. Geophys. Res., 109(D4), D04202, doi:10.1029/2003JD003940, 2004.

Maria, S. F., Russell, L. M., Gilles, M. K., and Myneni, S. C. B.: Organic aerosol growth mechanisms and their climate-forcing implications, Science, 306(5703), 1921-1924, 2004.

Myhre, G., Bellouin, N., Berglen, T. F., Berntsen, T. K., Boucher, O., et al.: Comparison of the radiative properties and direct radiative effect of aerosols from a global aerosol model and remote sensing data over ocean, Tellus, 59(1), 115-129, 2007.

Myhre, G., Berglen, T. F., Johnsrud, M., Hoyle, C. R., Berntsen, T. K., Christopher, S. A., Fahey, D. W., Isaksen, I. S. A., Jones, T. A., Kahn, R. A., Loeb, N., Quinn, P., Remer, L., Schwarz, J. P., and Yttri, K. E.: Modelled radiative forcing of the direct aerosol effect with multi-observation evaluation, Atmos. Chem. Phys., 9, 1365-1392, doi:10.5194/acp-9-1365-2009, 2009.

Novakov, T., Ramanathan, V., Hansen, J. E., Kirchstetter, T. W., Sato, Mki., Sinton, J. E., and Satahye, J. A.: Large historical changes of fossil-fuel black carbon aerosols, Geophys. Res. Lett., 30(6), 1324, doi:10.1029/2002GL016345, 2003.

Olivier, J. G., Berdowski, J. J. M., Peters, J. A. H. W., Bakker, J., Visschedijk, A. J. H., and Bloos, J. P. J.: Applications of EDGAR. Including a description of EDGAR 3.2: reference database with trend data for 1970-1995, RIVM, Bilthoven. RIVM Report 773301 001/NRP Report 410200 051, 2002.
Petzold, A., Döpelheuer, A., Brock, C. A., and Schröder, F.: In-situ observations and model calculations of black carbon emission by aircraft at cruise altitude, J. Geophys. Res., 104(D18), 2217122181, 1999.

Rossow, W. B. and Schiffer, R. A.: Advances in understanding clouds from ISCCP, B. Am. Meteorol. Soc., 90, 2261-2287, 1999.

Sausen, R., Isaksen, I., Grewe, V., Hauglustaine, D., Lee, D. S., Myhre, G., Kohler, M. O., Pitari, G., Schumann, U., Stordal, F., et al.: Aviation radiative forcingin 2000: an update of IPCC (1999), Meteorol. Z., 14, 555-561, 2005.

Schulz, M., Textor, C., Kinne, S., Balkanski, Y., Bauer, S., Berntsen, T., Berglen, T., Boucher, O., Dentener, F., Guibert, S., Isaksen, I. S. A., Iversen, T., Koch, D., Kirkevåg, A., Liu, X., Montanaro, V., Myhre, G., Penner, J. E., Pitari, G., Reddy, S., Seland, Ø., Stier, P., and Takemura, T.: Radiative forcing by aerosols as derived from the AeroCom present-day and pre-industrial simulations, Atmos. Chem. Phys., 6, 5225-5246, doi:10.5194/acp-6-5225-2006, 2006.

Schultz, M. G., Feichter, J., and Léonardi, J.: Climatic impact of surface transport, in: Issues in Environmental Science and Technology, 20, Transport and the environment, ISSN 1350-7583, 111-127, 2004.

Stamnes, K., Tsay, S. C., Wiscombe, W., and Jayaweera, K.: Numerically Stable Algorithm For Discrete-Ordinate-Method Radiative-Transfer In Multiple-Scattering And Emitting Layered Media, Appl. Optics, 27(12), 2502-2509, 1988.

Stier, P., Seinfeld, J. H., Kinne, S., Feichter, J., and Boucher, O.: Impact of non-absorbing anthropogenic aerosols on clearsky atmospheric absorption, J. Geophys. Res., 111, D18201, doi:10.1029/2006JD007147, 2006.

Swietlicki, E., Zhou, J. C., Berg, O. H., Martinsson, B. G., Frank, G., Cederfelt, S. I., Dusek, U., Berner, A., Birmili, W., Wiedensohler, A., Yuskiewicz, B., and Bower, K. N.: A closure study of sub-micrometer aerosol particle hygroscopic behaviour, Atmos. Res., 50(3-4), 205-240, 1999.

Toon, O. B. and Pollack, J. B.: A global average model of atmospheric aerosols for radiative transfer calculation, J. Appl. Meteorol., 15, 226 pp., 1976.

Turpin, B. J., Huntzicker, J. J., and Hering, S. V.: Investigation of organic aerosol sampling artifacts in the Los Angeles Basin, Atmos. Environ., 28, 3061-3071, 1994.

Unger, N., Bond, T. C., Wang, J. S., Koch, D. M., Menon, S., Shindell, D. T., and Bauer, S.: Attribution of climate forcing to economic sectors, PNAS, 107(8), 3382-3387, doi:10.1073/pnas.0906548107, 2010.

WCP: A preliminary Cloudless Standard Atmosphere for Radiation Computation, World Meteorological Organisation, WCP report $122,1986$.

Wentzel, M., Gorzawski, H., Naumann, K. H., Saathoff, H., and Weinbruch, S.: Transmission electron microscopical and aerosol dynamical characterization of soot aerosols, J. Aerosol Sci., 34(10), 1347-1370, 2003.

Yanowitz, J., McCormick, R. L., and Graboski, M. S.: In-Use emissions from heavy-duty diesel vehicles, Environ. Sci. Technol., 34 (5), 729-740, doi:10.1021/es990903w, 2000. 